\title{
Gender Bias in the Allocation of Welfare Programs in the Muslim Community, Reasons and Remedies: A Study on Orphanages in Kerala
}

\author{
Muhammed Ashique PP \\ Doctoral Fellow, Dept. of Economics, Maulana Azad National Urdu University, Hyderabad, Telangana, India \\ E-mail: ppbusthani@gmail.com
}

\begin{abstract}
The orphanage system in Kerala is a well-organized welfare-oriented Institution to provide education and livelihood for the orphans. Even though the orphanage system makes a tremendous change in the Empowerment of orphans, there is a huge gap between the allocation of orphanages for boys and girls orphans. The gender gap exists in all the institutions in the state, but it is at the peak in the institutions under religious minority. This gap is a serious issue in a state where the sex ratio is $\mathbf{1 . 0 8}$ which is the highest in the country. This research paper is trying to find the reasons for the gender gap in Muslim orphanages and suggesting possible remedies to overcome the issue.
\end{abstract}

Keywords: Gender Bias, Welfare Programs, Orphanages

\section{INTRODUCTION}

Human resource development is the process of enabling or increasing the efficiency and ability of citizen by giving proper knowledge or skill to make him/her a more demanded product in the labour market. At the same time, human resource development is much important for both market and people as lack of human resources will create labour crisis in the market and unemployment will bring poverty to people individually and it will lead to the socioeconomic exclusion of the victim from the mainstream. This shows the importance of preparing the coming generation for the market need. It is important to ensure the availability of resources to up skill all the classes of society. Here, the orphans in the society seem to be excluded from the availability of opportunities as they lost their breadwinner of the family and survive to live. For the betterment of this community, a new initiative was developed in Kerala as an orphanage system (Osella \& Osella, 2008). As of available records, the first orphanage in Kerala was established in Kozhikkode by JDT Islam in 1922(Parappil, 1994).

The orphanage system was found by the religious congregations to uplift the poor people among their community (Chaves, 1999). The orphanage system in Kerala is a well-established government-protected agency under the social welfare department which aims to improve the living standard of orphans in the state (Usman, 2005). According to the official estimate of the Association of Orphanages and Charitable institutions there are 1699 orphanages in the state which gives protection to 34005 in mates (AOCI, 2016).
Normally the orphanages take inmates to the 5th standard and give quality education. After completion of 10th standard, students are advised to sit for an aptitude test and they are guided for higher studies under the orphanage management itself. Normally all the expenses of these higher studies are incurred by the institution itself. If we take the percentage share of various religious organisations running orphanages, 72.27 percentage are under Christian missionaries and 23.9 are under Muslim management (Kareem, 1991). From the above data, we can see the role of this institution in the empowerment of a marginalized sect inside a backward community.

TABLE I DISTRICT-WISE GROWTH OF THE ORPHANAGE SYSTEM

\begin{tabular}{|l|c|c|}
\hline Districts & $\begin{array}{c}\text { Orphanages in } \\
\mathbf{2 0 1 4 - 1 5}\end{array}$ & $\begin{array}{c}\text { Orphanages in } \\
\mathbf{2 0 1 5 - 1 6}\end{array}$ \\
\hline Kasarkode & 49 & 40 \\
\hline Kannur & 130 & 131 \\
\hline Vayanad & 67 & 67 \\
\hline Kozhikkode & 103 & 103 \\
\hline Malappuram & 98 & 98 \\
\hline Palakkad & 115 & 117 \\
\hline Thrisur & 256 & 256 \\
\hline Eranakulam & 234 & 236 \\
\hline Idukki & 122 & 124 \\
\hline Alappuzha & 75 & 75 \\
\hline Kottayam & 209 & 210 \\
\hline Kollam & 71 & 71 \\
\hline $\begin{array}{l}\text { Pathanamthitt } \\
\text { a }\end{array}$ & 53 & 53 \\
\hline $\begin{array}{l}\text { Thiruvananth } \\
\text { apuram }\end{array}$ & 107 & 109 \\
\hline \multicolumn{1}{|c|}{ Total } & 1689 & 1699 \\
\hline
\end{tabular}

Source: Association of orphanages and charitable institutions, Kerala. Annual report 2015-16

The above table shows the growth of the orphanage system district wise which points out that the need for the same is increasing. Religious organisations are taking appreciative efforts in starting new institutions in needful places and progressive steps in implementing the modernisation of the orphanages. This will help the needful people to get admitted to the nearest institutions. At the same time, the 
allocation of orphanages shows a negative relationship between the total number of orphanages and the number of girl's orphanages in the state (Padmam, 2003). It is disgusting that according to the 2011 Census report, Kerala is a state where the sex ratio is 1.08 which is the highest in the country(Census, 2011).
The number of girl's orphanages is too less compared to that of boy's orphanages. Given graph shows the gender variation in orphanages of Malappuram district in taluk wise which is the most Muslim populated district in the state. See Fig.1

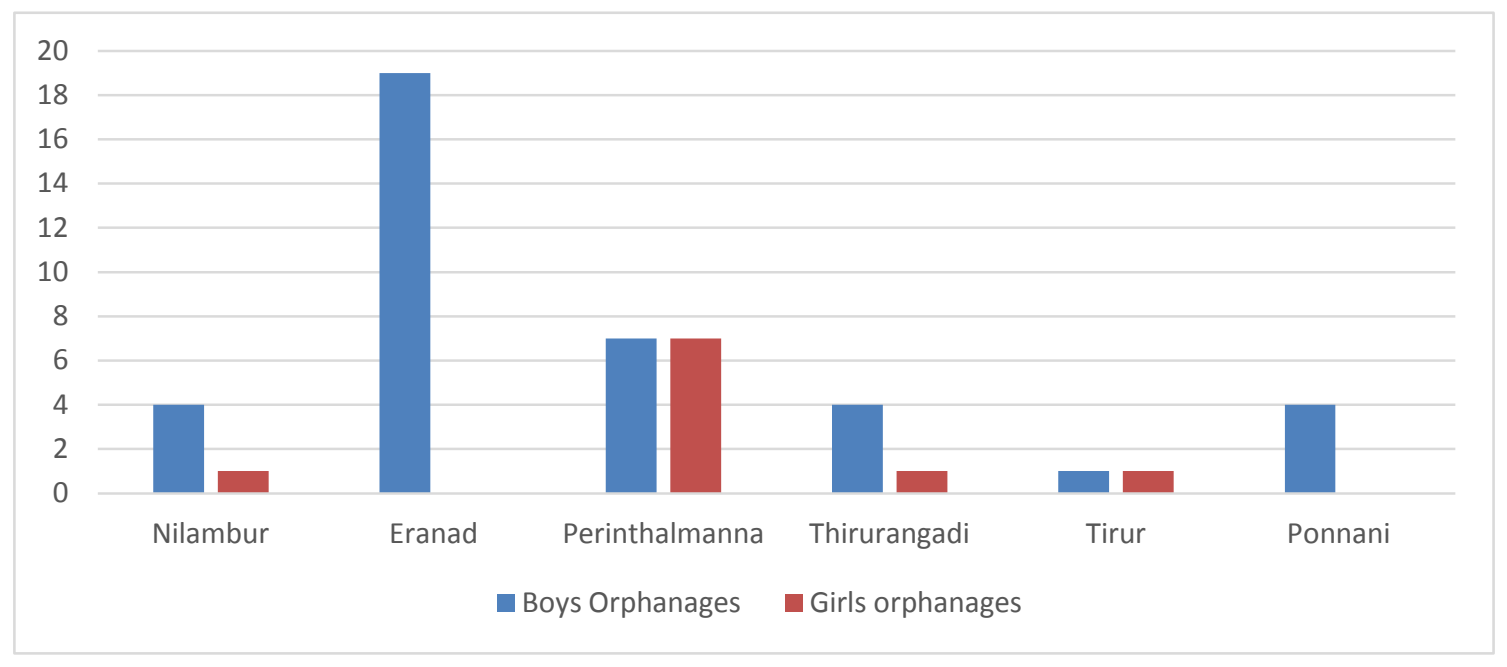

Fig.1 Gender wise allocation of orphanages in Malappuram District

The above Graph shows the gap between the orphanages available for boys and girls. Other districts are not much better in this discrimination. We can see the huge gap between the availability of Boy's and Girl's orphanages. Only in Perinthalmanna taluk, we have an equal distribution of orphanages for both boy and girl orphans. In Ponnani and Eranad Taluk we don't have girl's orphanages at the same time Eranad taluk has the highest number of orphanages in the district. The above orphanages are included in all religious institutions.

According to the report of the Social Justice Department, Government of Kerala there is only 11 Muslim Girl's only orphanages in the state. It is to be noted that the total number of orphanages under Muslim management is 407. This huge gender gap shows there are some issues with establishing girl's orphanages. This article is trying to understand the reasons and suggesting the remedies in the gender gap in the allocation of orphanages in the Muslim community

\section{CULTURAL BARRIERS}

One of the main problems is cultural barriers in society. The orphans will be from a poor financial background, in Kerala a girl child from poor families is not encouraged for higher education. Their education will end-up in Higher secondary or a diploma course after regular schooling. This mindset of guardians/caretakers of orphans will lead to planning the marriage of a girl child after her schooling (most of the time it happens with the help of society or religious organisations). Because of this, the guardians will hesitate to send the girl child to orphanages as they are not giving importance in educating them. As a result of this, the consequences of early marriage are being reported. These women will not be able to become self-sufficient as they don't have a vocational education and they will be a dependent person in her entire life.

To overcome this problem a root level initiative should be done. The awareness should start from the family by making them understand the importance of educating the girl orphans. The orphan girl is not supposed to depend on the society in her entire life. They should become selfsufficient so that they can face financial or social issues independently in the future.

\section{INTENTION OF THE SYSTEM}

All the existing girl's orphanages are intending to help the inmates with food and accommodation and some orphanages provide some basic vocational training like handicrafts, tailoring, and cooking until they reach eighteen years old. After that these inmates are sent for marriage as soon as possible, but the boy's orphanages are providing every guidance and financial help until the inmate is settled in a job with a good education. Here as far as the girl's orphanages didn't promote higher education, the inmates of orphanages will be only those who are starving at home or don't have a shelter. If the girl's orphanages also focus on higher education of the inmates, it will attract more inmates who are leaving education because of the financial crisis. For this, the organisations should change the intention of girls' orphanage from a feeding home to a centre of excellence. 


\section{RISKS IN STARTING GIRL'S ORPHANAGES}

The facilities to be provided in girl's orphanages are higher compared to the boy's orphanages considering the security risk of inmates. In fact, the managements of girl's orphanages are afraid of this security risk. The religious organisations are not merely focusing on the development of a community but they will think twice when the risk increases. The administrative laws are also an issue as there are many procedures than that of a boy's orphanage to start a girl's orphanage, including taking permissions from both government and non-government authorities like women's cell. Getting permission from these administrative bodies is somehow difficult as the exploitation of girl's orphanages was reported earlier and the administrative laws became strict on allowing the orphanages. This will make the organisations think about not considering the girl's orphanages. By this girl orphans are missing their chance to get a better standard of living. The issue can be solved by proper planning of the bureaucratic law like a single window system for applying new institutions and making an organization friendly inspection system which will encourage faithful organisations to stay in the system.

\section{SOCIAL BARRIERS}

There are social barriers also which slow down the establishment of girl's orphanages. The religious leaders are not taking more initiatives to start a girl's orphanage as the consequences of happening issues will invite media attention and it will make a negative mark on the entire organization. On 7th March 2017, one molestation case was reported in an orphanage in Wayanad, Kerala. The inmates were sexually abused by some outsiders on the way to their schools. After the incident, this orphanage was permanently closed and other institutions under this organisation turned to boys only orphanages as a result of media attack on the institution. The organisations running orphanages for girls are not encouraged in public. The social interest in the marriage of an orphan girl child is not given for educating an orphan girl child. This shows the mindset of people towards educating the orphan child. This kind of negative attacks and non-cooperation from society also affects the running of this system. To overcome this the mentality of society towards the girl's orphanages should be changed from completing the social responsibility with the marriage of an orphan girl to considering a long-term investment in orphans as educating them and making them self-sufficient.

\section{FINANCIAL BURDEN AND GOVT. FUNDING}

The financial burden of starting a girl's orphanage is much higher considering that of the boy's orphanage as there are higher government restrictions on security and infrastructure facilities. Running of the girl's hostels will need the same as the availability of staff is also a big concern. At the same time, the government funds available for the boy's orphanages and girl's orphanages are the same in amount. It is very important to give special consideration to girl's orphanages in the state as there is a lack of it and there should be initiatives to empower the existing orphanages and to encourage new orphanages in society for the empowerment of girl orphans. Girl's orphanages will need more financial assistance to run the institution. This should be considered in serious and special financial assistance to these institutions will reduce the burden of the organizations running girl's orphanages and will attract more organisations to start girl's orphanages

\section{CONCLUSION}

The gender gap in the allocation of orphanages all over the state is a social issue that should be corrected. The available girl's orphanages itself are not considering to provide higher education for girl's, but it is only a "stay home" for them until they get married. This attitude is to be changed to provide higher education to orphan girls and making them self-sufficient. The orphanages for girls should change from a feeding home to a centre for educational excellence for girl orphans. The social and government help is not enough for the organisations in this field. The social mentality isto be changed from responsibility of society is to make a girl orphan get married to make them self-sufficient. Society must consider both boy and girl orphans in the same way and make availability of education to both of them. Social awareness should be done for this and to encourage organisations running girl's orphanages.

The government should implement schemes to protect the existing orphanages and consider giving more financial aids to girl's orphanages than that to boy's orphanages as the financial burden to run a girl's orphanage is higher than that of a boy's orphanage. The administrative laws on girl's orphanages should be more transparent and convincible to the orphanage management so that they feel free to follow the rules and cooperate with them.

\section{REFERENCES}

[1] AOCI. (2016). Annual Report. Thiruvananthapuram: Association of Orphanages and Charitable Institutions.

[2] Census. (2011). Primary Census Abstract. Registrar General of India, Ministry of Home Affairs, Governemnt of India.

[3] Chaves, M. (1999). Religious Congregations and Welfare Reform: Who Will Take Advantage of "Charitable Choice"? American Sociological Review, 64(6), 836-846.

[4] Kareem, C. (1991). Kerala Muslim Directory. Edappally: Charithram Publication.

[5] Osella, F., \& Osella, C. (2008). Islamism and Social Reform in Kerala, South India. Modern Asian Studies, 42(3), 317-346.

[6] Padmam, M. S. (2003). Destitute Women in Kerala: Psychological resources and psycho-social needs. Thiruvananthapuram: Centre For Development Studies.

[7] Parappil, M. K. (1994). Kozhikkotte Muslimkalude Charithram. Calicut: Focus Publications.

[8] Usman, M. (2005). The role of voluntary agencies in human resource creation: a case study of orphanages in Malappuram district. University of Calicut . 